\title{
A two-stage stochastic programming model for industrial adjustment on water and energy resources in Guangdong Province, China
} Wencong Yue ${ }^{1,2, a}$, Yanpeng Cai ${ }^{4 b,}$, Meirong $\mathrm{Su}^{2, \mathrm{c}^{*}}$, Zhi Dang $^{1, \mathrm{~d}^{*}}$, Mianmian Wang
Zhifeng Yang

${ }^{1}$ School of Environment and Energy, South China University of Technology, Guangzhou, Guangdong, 510006, China;

${ }^{2}$ Research Center for Eco-Environmental Engineering, Dongguan University of Technology, Dongguan, 523808, China;

${ }^{3}$ Dongguan Cleaner Production Center, Dongguan University of Technology, Dongguan, 523808, China;

${ }^{4}$ State Key Laboratory of Water Environment Simulation, School of Environment, Beijing Normal University, Beijing, 100875, China;

Corresponding author: Dr. Meirong Su and Dr. Zhi Dang

ayuewc@dgut.edu.cn, byanpeng.cai@bnu.edu.cn, 'sumr@dgut.edu.cn, ${ }^{\mathrm{d}}$ chzdang@scut.edu.cn, ewangxuemian@163.com, ${ }^{\mathrm{t}}$ zfyang@bnu.edu.cn

Keywords: Industrial adjustment; Two-stage stochastic programming; Water resources; Energy. Abstract. A two-stage stochastic programming (TSP) model is effective for industrial adjustment under limited and varied capacities of water and energy resources. In this paper, industrial adjustment in the future (i.e., the 13th five-year plan) was evaluated by a eatablished TSP model under limited and uncertain supply of water and energy resources. The developed method was demonstrated in Guangdong Province of China. The results indicated that the first-stage industrial planning would not be influenced by water and energy supply capacities when water supply would be sufficient (i.e., 8938 million $\mathrm{m}^{3}$ ). When the probability of water supply capacities would be 4491 million $\mathrm{m}^{3}$, economic benefits of three types of industries (i.e., manufacture of electrical machinery and equipment, textile garments, footwear and headgear, as well as food and tobacco) would reduce over 70 billion yuan.

\section{Introduction}

Over the past decades, with the rapid trends of urbanization and industrialization, many cities in China face dual challenges from resource shortage and industrial development. Thus, allocation of energy and water resources was extensively paid attention to by many studies throughout the world ${ }^{1}$. Mathematical programming methods, such as two-stage stochastic programming (TSP), were widely applied for addressing problems of resource allocation ${ }^{2}$. For example, Zhen et al. ${ }^{3}$ developed a TSP model for supporting regional electric power system management. Wang et al. ${ }^{4}$ developed a TSP model in consideration of imprecise probabilities for supporting water resources management. However, water and energy supply capacities was seldom considered in industrial adjustment. Therefore, the objective of this study is to develop a two-stage stochastic programming model for supporting comprehensive decision-making in industrial adjustment under uncertain supply of water and energy resources. The developed method will then be demonstrated in Guangdong Province of China. 


\section{Methods}

Consider a problem in which a manager is responsible for allocating water and energy to multiple industrial users ${ }^{1}$. The manager can formulate the problem of industrial adjustment in water and energy resources respective through maximizing the economic benefits of industrial products in consideration of economic benefits, water and energy demands, and economic goals. A two-stage stochastic programming model is effective for industrial adjustment under limited and varied capacity of water and energy resources. In the first-stage decision-making process, it is assumed that amount of water and energy supply could meet demands of all water and energy users before any random changes ${ }^{5}$. Under occurrences of random seasonal flows, adjustment need be taken to balance multiple industrial users as a result of the first-stage decision. Thus, the problem can be described by the following equations:

$\max f=\sum_{j=1}^{22} t_{j}-\sum_{j=1}^{22} \sum_{i=1}^{3} p_{i} x_{i j}$

s.t.

$t_{j}-x_{i j} \geq 0, \forall i, j$

$\sum_{l=1}^{3} C_{i l} \geq \sum_{j=1}^{22} c_{j} \times\left(t_{j}-x_{i j}\right)+C_{A}+C_{R}, \forall i$

$E \geq \sum_{j=1}^{22} e_{j} \times\left(t_{j}-x_{i j}\right)+E_{A}+E_{R}$

$x_{i j} \geq 0, \forall i, j$

$y_{j} \geq 0, \forall j$

where $f$ : Economic benefit of industrial production;

$t_{j}$ : Plan for the $j^{\text {th }}$ industry;

$x_{i j}$ : Shortage of Output on the $j^{\text {th }}$ industry in the second-stage decision making when water available probabilities is $p_{i}$;

$C_{i l}$ : Water supply capacity of the $l^{\text {th }}$ water source when water available probabilities is $p_{i}$;

$c_{j}$ : Water consumption intensity of the $j^{\text {th }}$ industry;

$C_{A}$ : Amount of water for agriculture;

$C_{R}$ : Amount of water for social user (e.g., residents, schools, and hospitals);

$E$ : Energy supply capacity;

$e_{j}$ : Energy consumption intensity of the $j^{\text {th }}$ industry;

$E_{A}$ : Amount of energy for agriculture;

$E_{R}$ : Amount of energy for social user (e.g., residents, schools, and hospitals).

\section{Case study}

Located in southern China, Guangdong Province has been the largest contributor of GDP among all the provinces in China since $1989^{6}$. For example, Guangdong's GDP accounts for $10.6 \%$ of the total GDP of Mainland China in 2015. Also, the province consumed large amount of energy and water resources with rapid trends of urbanization and industrialization ${ }^{8}$. Under this situation, Guangdong Province faces dual challenges from resource shortage and industrial development. Also, there will be tremendous pressure on Guangdong to realize this goal during the period of the 13th five-year plan (2016-2020) ${ }^{7}$. 
Data preparation Water and energy supply capacities are shown in Table 1. Parameters on industrial plans of Guangdong Province are described by Tables 2 to 4 .

Table 1 Water and energy supply capacities of Guangdong Province

\begin{tabular}{llll}
\hline Item & Probabilities & Unit & 2020 \\
\hline \multirow{3}{*}{ Water supply } & $10 \%$ & & 89.38 \\
& $50 \%$ & 100 million m $^{3}$ & 64.48 \\
& $90 \%$ & & 44.91 \\
\hline Energy supply capacity & - & 10000 t of SCE $^{*}$ & 19103 \\
\hline
\end{tabular}

*Note: SCE - standard coal equivalent

Table 2 Industrial plans of Guangdong Province

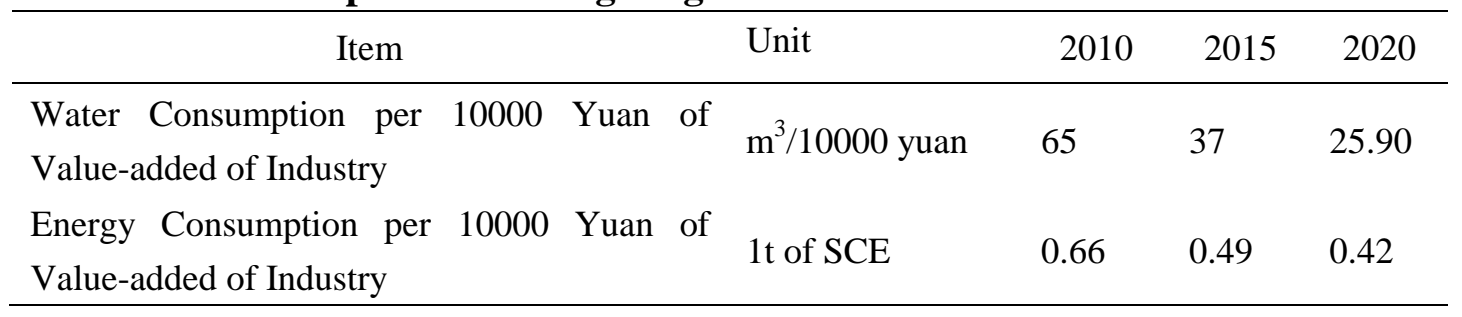

Table 3 Code numbers of industries in case study

\begin{tabular}{|c|c|c|c|}
\hline Types of industries & Number & Types of industries & Number \\
\hline Extraction of Petroleum and Natural Gas & 1 & Smelting and Pressing of Metals & 12 \\
\hline Mining and Dressing of Metal Ores & 2 & Metal Products & 13 \\
\hline Mining and Dressing of Nonmetal Ores & 3 & $\begin{array}{l}\text { Manufacture of General-purpose } \\
\text { Machinery }\end{array}$ & 14 \\
\hline Manufacture of Food and Tobacco & 4 & $\begin{array}{l}\text { Manufacture of Special-purpose } \\
\text { Machinery }\end{array}$ & 15 \\
\hline Textile Industry & 5 & Manufacture of Transport equipment & 16 \\
\hline $\begin{array}{l}\text { Manufacture of Textile Garments, } \\
\text { Footwear and Headgear }\end{array}$ & 6 & $\begin{array}{l}\text { Manufacture of Electrical Machinery } \\
\text { and Equipment }\end{array}$ & 17 \\
\hline $\begin{array}{l}\text { Timber Processing, Bamboo, Cane, Palm } \\
\text { Fiber \& Straw, and Furniture }\end{array}$ & 7 & $\begin{array}{l}\text { Manufacture of Communication } \\
\text { Equipment, Computers and Other } \\
\text { Electronic Equipment }\end{array}$ & 18 \\
\hline Papermaking, Printing & 8 & Manufacture of Instruments and Meters & 19 \\
\hline $\begin{array}{l}\text { Petroleum Refining, Coking and Nuclear } \\
\text { Fuel Processing }\end{array}$ & 9 & Other Manufactures & 20 \\
\hline Manufacture of Chemical Products & 10 & Comprehensive Utilization of Waste & 21 \\
\hline Nonmetal Mineral Products & 11 & $\begin{array}{l}\text { Manufacture of Metal Products, } \\
\text { Machinery and Equipment Maintenance }\end{array}$ & 22 \\
\hline
\end{tabular}


Table 4 Industrial demands and plans in Guangdong Province

\begin{tabular}{cccc}
\hline \multirow{2}{*}{$\begin{array}{c}\text { Types of } \\
\text { industries }\end{array}$} & $\begin{array}{c}\text { Water consumption } \\
\text { intensity }\end{array}$ & $\begin{array}{c}\text { Energy consumption } \\
\text { intensity }\end{array}$ & $\begin{array}{c}\text { Plan for economic } \\
\text { benefits in 2020 }\end{array}$ \\
\cline { 2 - 4 } $\mathrm{m}^{3} / 10000$ yuan & 1 ton of SCE/10000 yuan & 100 million yuan \\
\hline 1 & 0.07 & 0.18 & 383 \\
2 & 23.21 & 0.39 & 67 \\
3 & 8.70 & 0.51 & 128 \\
4 & 14.91 & 0.39 & 2386 \\
5 & 30.85 & 1.26 & 751 \\
6 & 7.22 & 0.30 & 2184 \\
7 & 12.03 & 0.40 & 1010 \\
8 & 14.33 & 1.01 & 2246 \\
9 & 0.90 & 1.91 & 811 \\
10 & 12.56 & 0.83 & 2185 \\
11 & 12.13 & 2.94 & 1236 \\
12 & 37.89 & 3.61 & 365 \\
13 & 16.57 & 0.47 & 1354 \\
14 & 6.74 & 0.24 & 806 \\
15 & 7.88 & 0.29 & 697 \\
16 & 2.37 & 0.18 & 1706 \\
17 & 5.50 & 0.25 & 3618 \\
18 & 3.12 & 0.21 & 6500 \\
19 & 4.18 & 0.30 & 253 \\
20 & 5.76 & 0.78 & 65 \\
21 & 2.66 & 0.16 & 247 \\
22 & 10.86 & 0.37 & 77 \\
\hline
\end{tabular}

Table 5 Planning modifications (i.e., $x_{i j}$ ) of industries in Guangdong Province

\begin{tabular}{cccc}
\hline $\begin{array}{c}\text { Types of } \\
\text { industries }\end{array}$ & & Probabilities $\left(p_{i}\right)$ & \\
\cline { 2 - 4 } 1 & $10 \%$ & $50 \%$ & $90 \%$ \\
2 & 0.00 & 0.00 & 29.00 \\
3 & 0.00 & 28.90 & 56.23 \\
4 & 0.00 & 0.00 & 749.84 \\
5 & 0.00 & 0.00 & 259.27 \\
6 & 0.00 & 259.27 & 754.46 \\
7 & 0.00 & 0.00 & 296.18 \\
8 & 0.00 & 0.00 & 673.76 \\
9 & 0.00 & 0.00 & 0.00 \\
10 & 0.00 & 0.00 & 655.58 \\
11 & 0.00 & 0.00 & 545.04 \\
12 & 0.00 & 0.00 & 160.75 \\
13 & 0.00 & 160.75 & 597.08 \\
14 & 0.00 & 0.00 & 355.46 \\
15 & 0.00 & 0.00 & 307.19 \\
16 & 0.00 & 0.00 & 0.00 \\
17 & 0.00 & 0.00 & 1113.39 \\
18 & 0.00 & 0.00 & 0.00 \\
19 & 0.00 & 0.00 & 0.00 \\
20 & 0.00 & 0.00 & 28.48 \\
21 & 0.00 & 0.00 & 0.00 \\
22 & 0.00 & 0.00 & 18.85 \\
\hline
\end{tabular}


Results and discussion The solutions for planning modifications of industries in Guangdong Province are showed in Table 5. The results indicated that the first-stage industrial planning would not be influenced by water and energy supply capacities when water supply would be sufficient (i.e., 8938 million $\mathrm{m}^{3}$ ). When the probability of water supply capacities would be 4491 million $\mathrm{m}^{3}$, economic benefits of three types of industries (i.e., manufacture of electrical machinery and equipment, textile garments, footwear and headgear, as well as food and tobacco) would reduce more than 70 billion yuan.

\section{Conclusions}

A two-stage stochastic programming model is effective for industrial adjustment under limited and varied capacities of water and energy resources. In this paper, industrial adjustment in the future (i.e., the 13th five-year plan) was evaluated with limited water and energy resources under occurrences of random seasonal flows. The results indicated the first-stage industrial planning would not be influenced by water and energy supply capacities. When the probability of water supply capacities is 4491 million $\mathrm{m}^{3}$, economic benefits of three types of industries (i.e., manufacture of electrical machinery and equipment, textile garments, footwear and headgear, as well as food and tobacco) would reduce more than 70 billion yuan.

\section{Acknowledgements}

This work was supported by the National Key Research Program of China (Grant No. 2016YFC0502806), the Fund for Innovative Research Group of the National Natural Science Foundation of China (Grant No. 51421065), the National Natural Science Foundation of China (No. 41371482, 71673027), the Funds for International Cooperation and Exchanges of the National Natural Science Foundation of China (No. 51661125010), and the Social Science Project of Zhejiang Province (12JCJJ10YB).

\section{References}

[1] Y. P. Cai, G. H. Huang, Q. Tan and Z. F. Yang, Renewable Energy 34, 1833 (2009)

[2] J. Xu, G. Huang, Z. Li and J. Chen, Environmental Science and Pollution Research 24, 12437 (2017)

[3] J. L. Zhen, G. H. Huang, W. Li, C. S. Wu and S. Wang, Journal of Cleaner Production 139, 1308 (2016)

[4] Y. Y. Wang, G. H. Huang, S. Wang and W. Li, Stochastic Environmental Research and Risk Assessment 30, 2169 (2016)

[5] Y. Cai, W. Yue, L. Xu, Z. Yang and Q. Rong, Resources, Conservation and Recycling 108, 21 (2016)

[6] Z. Cao, Z. Wu, Y. Kuang, N. Huang and M. Wang, Coupling an Intercalibration of Radiance-Calibrated Nighttime Light Images and Land Use/Cover Data for Modeling and Analyzing the Distribution of GDP in Guangdong, China. Sustainability 8, 108 (2016)

[7] P. Wang and B. Zhu, Sustainability 2016, 8, 355 (2016) 